\title{
Academic Institutions Risk Decisions using Six Thinking Hats Based Analysis
}

\author{
Pradeep Kumar Rangi ${ }^{1} \&$ P. S. Aithal ${ }^{2}$ \\ ${ }^{1}$ Research Scholar, College of Management \& Commerce, Srinivas University, Mangalore, \\ India \\ OrcidID: 0000-0002-2052-9054; E-mail: pradeep.rangi@gmail.com \\ ${ }^{2}$ Professor, College of Management \& Commerce, Srinivas University, Mangalore, India \\ OrcidID: 0000-0002-4691-8736; E-mail: psaithal@gmail.com
}

Area of the Paper: Business Management.

Type of the Paper: Research Paper.

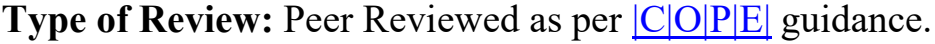

Indexed In: OpenAIRE.

DOI: http://doi.org/10.5281/zenodo.4427258

Google Scholar Citation: IJCSBE.

\section{How to Cite this Paper:}

Pradeep Kumar Rangi \& Aithal, P. S. (2020). Academic Institutions Risk Decisions using Six Thinking Hats Based Analysis. International Journal of Case Studies in Business, IT, and Education (IJCSBE), 4(2), 270-279. DOI: http://doi.org/10.5281/zenodo.4427258

International Journal of Case Studies in Business, IT and Education (IJCSBE)

A Refereed International Journal of Srinivas University, India.

(C) With Authors.

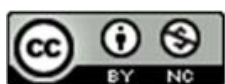

This work is licensed under a Creative Commons Attribution Non-Commercial 4.0 International License subject to proper citation to the publication source of the work.

Disclaimer: The scholarly papers as reviewed and published by the Srinivas Publications (S.P.), India are the views and opinions of their respective authors and are not the views or opinions of the S.P. The S.P. disclaims of any harm or loss caused due to the published content to any party. 


\title{
Academic Institutions Risk Decisions using Six Thinking
} Hats Based Analysis

\author{
Pradeep Kumar Rangi ${ }^{1} \&$ P. S. Aithal ${ }^{2}$ \\ ${ }^{1}$ Research Scholar, College of Management \& Commerce, Srinivas University, Mangalore, \\ India \\ OrcidID: 0000-0002-2052-9054; E-mail: pradeep.rangi@gmail.com \\ ${ }^{2}$ Professor, College of Management \& Commerce, Srinivas University, Mangalore, India \\ OrcidID: 0000-0002-4691-8736; E-mail: psaithal@gmail.com
}

\begin{abstract}
Today, almost everyone faces extraordinary health, social, and economic risk due to the COVID-19 pandemic. As for all industries, academic institutions face unprecedented challenges and are witnessing the change in short-and long-term risk profile due to COVID19 , e.g., enhanced information and cybersecurity risk due to the adoption of new collaboration tools, deterioration in the effectiveness of traditional fraud risk mitigants as enrollment and document verifications over email, and increased risk of financial viability. In addition to having a robust risk management framework, it is critical for the institutions to carefully recognize and mitigate these emerging risks, which may have long-term implications on the institution's academic performance and perpetuity. Educational institutions, therefore, must adopt a broad spectrum of thinking methods that allow a practical framework for risk decisions and provide a strong foundation for academic institutions to function and enforce strategies both throughout and after the COVID-19 period. With the help of an example, this paper explores how "Six Thinking Hats" may serve as a decision aid and facilitate the risk decisions in an academic institution around risk appetite, risk identification, risk assessment, control design, and risk monitoring. The "Six Thinking Hats" or colors are all about gaining direction, i.e., what can happen (threat and opportunities; effect and probability) and not merely about explaining the event, what is or what has happened. Risk management being forward-looking, this is a significant risk decision consideration. The paper also analyzes the "Six Thinking Hats" method using the ABCD analysis framework as a research case study.
\end{abstract}

Keywords: Risk Management, COVID-19, Six Thinking Hats, Risk Decisions, ABCD framework

\section{INTRODUCTION :}

COVID-19 has provided enough evidence that organizations of all sorts face daunting environmental, political, socio-economic, and cultural forces that make their operational environments unpredictable. These factors contribute to the uncertainty. Therefore, the effect and probability of these underlying factors can stop institutes from achieving objectives or missions. Some degree of risk is always implicit and inherent in the strategy and processes implemented or proposed by the academic institute. Therefore, it is critical that institutions systematically identify, mitigate, monitor, and exercise risk decisions risk in a manner that is acceptable within the targeted risk tolerance and appetite of the academic institutions to achieve their mission [1]-[4]. Change in the external environment requires that the institute's risk profile be reviewed to ensure that risk application and decisions are proportionate to the change in underlying risk inherent in the institute's operations. COVID-19 and similar significant external events may require institutions to reassess their risk appetite in academic mission, strategic growth, student experience, research, teaching, financial viability, reputation and safety, and health. Significant changes in the external environment require that the institute's risk profile and appetite are recalibrated and adjust to any underlying risk change. Begin with revisiting the academic institution's risk appetite related to its educational goal, strategic growth goals, financial health, learning environment, research goals, reputation, health, and safety. The likely impact of such uncertainties may 
be pervasive, and to achieve a well-rounded risk decision broad spectrum of thinking methods is required. Dr. Edward de Bono provided a robust and effective strategy called the "Six Thinking Hats" [5]. The model's fundamental concept is parallel thinking, a framework where people can explore different perspectives collectively without intervention from other forms of thought. White hat allows decision-makers to remain neutral and analytical; Red helps consider subjective and emotional viewpoints associated with judgment. Black would allow for a cautious and careful approach; Yellow ensures that we are not too pessimistic and think an optimistic view; Green encourages imagination and innovative thoughts. Finally, the Blue hat is associated with control, the arrangement of the thinking method, and other hats [5], [6]-[13]. Therefore, it provides team members and decision-makers an opportunity to substantially decrease meetings' timing and increase the consistency and pace of brainstorming and decision-making.

In the COVID-19 environment, though fundamentally the academic institution's mission and objectives remain unchanged, some critical areas of the institute's risk profile may have impaired. For example: (a) enhanced information and cybersecurity risk as faculty, staff, and students have adopted new online collaboration tools. (b) deterioration in the effectiveness of traditional fraud mitigants, e.g., new enrollment threat may be based on fake documents, duplicate or fraudulent payment. (c) The increased risk of financial viability resulted from reduced registration (inter-state, city students), unbudgeted expenses, e.g., buying new collaboration software, and loss of other income from events. The alteration in these areas of institutes risk profile requires a careful risk assessment and risk decisions, not merely but one mode of thinking. "Six Thinking Hat" is a lateral thinking tool and can enhance the effectiveness of risk decision making process. Hats are about gaining direction, i.e., what can happen (threat and opportunities; effect and probability), and not only about explaining the event, what is or what has happened. The "Six Thinking Hats" technique will aid the enterprise risk management framework adopted by the academic institute. As a tool, it enables an opportunity to consider the full discussion, promote transparency, and cross-functional participation in risk decisions. With the help of an example, this paper explores how "Six Thinking Hats" may serve as a decision aid and facilitate the risk decisions in an academic institution around risk appetite, risk identification, risk assessment, control design, and risk monitoring. The article does not take a rigorous test of "Six Thinking Hat" types in risk decisionmaking areas; however, it explores application through examples. Researchers and future work may find this to be a useful line of inquiry.

\section{RELATED WORKS :}

Academic scholars have made a significant contribution to enhancing the understanding of "Six Thinking Hats" methods, introduced a novel way of its applications by integrating them with other practices and fields of use, e.g., ABCD and Theory A [6]-[11]. — Some of the academic written articles on the "Six Thinking Hats" methods as a tool for problem-solving and decision-making are outlined below in Table 1.

Table 1: Related publications on the (a) "Six Thinking Hats" method and its application, and (b) Academic institutions risk management

\begin{tabular}{|l|l|l|}
\hline S. No. & \multicolumn{1}{|c|}{ Themes } & \multicolumn{1}{c|}{ Focus Area } \\
\hline 1 & $\begin{array}{l}\text { "Six Thinking } \\
\text { Hats" methods }\end{array}$ & $\begin{array}{l}\text { How to adopt "Six Thinking Hats" methods in the problem-solving } \\
\text { process (both individual and group) [6] }\end{array}$ \\
\hline 2 & $\begin{array}{l}\text { "Six Thinking } \\
\text { Hats" methods } \\
\text { and Theory A }\end{array}$ & $\begin{array}{l}\text { How to integrate theory A and Six Thinking Hats Technique to } \\
\text { enhance entities performance [6] }\end{array}$ \\
\hline 3 & $\begin{array}{l}\text { "Six Thinking } \\
\text { Hats" methods } \\
\text { and ABCD } \\
\text { Framework }\end{array}$ & $\begin{array}{l}\text { Adopting "Six Thinking Hats" using ABCD Framework [7], [10], } \\
{[12],[13]}\end{array}$ \\
\hline
\end{tabular}




\begin{tabular}{|l|l|l|}
\hline 4 & $\begin{array}{l}\text { "Six Thinking } \\
\text { Hats" methods }\end{array}$ & $\begin{array}{l}\text { Optimum and an ideal decision making in critical situations adopting } \\
\text { "Six Thinking Hats" method [6]-[13] }\end{array}$ \\
\hline 5 & $\begin{array}{l}\text { "Six Thinking } \\
\text { Hats" methods }\end{array}$ & Managerial decision process adopting "Six Thinking Hats" [10] \\
\hline 6 & $\begin{array}{l}\text { Risk } \\
\text { Management }\end{array}$ & $\begin{array}{l}\text { Understanding of risk management and its effect on academic } \\
\text { institutions (university) [1] }\end{array}$ \\
\hline 7 & $\begin{array}{l}\text { Risk } \\
\text { Management }\end{array}$ & $\begin{array}{l}\text { Risk management practice in a university ecosystem or environment } \\
{[14]}\end{array}$ \\
\hline 8 & $\begin{array}{l}\text { Risk } \\
\text { Management }\end{array}$ & Risk framework for a university setting [15] \\
\hline 9 & $\begin{array}{l}\text { Risk } \\
\text { Management }\end{array}$ & $\begin{array}{l}\text { Enterprise risk management framework and strategies deployed by } \\
\text { nonprofit business leaders [16] }\end{array}$ \\
\hline 10 & $\begin{array}{l}\text { Risk } \\
\text { Management }\end{array}$ & Risk management practices in the higher education institutions [17] \\
\hline
\end{tabular}

\section{OBJECTIVES OF THE STUDY :}

This paper explores how "Six Thinking Hats" strategies facilitate the review of risk profiles and each component of risk management methodology adopted by academic institutions,' i.e., risk appetite, risk identification, risk assessment, control design, risk monitoring, and reporting. To study "Six Thinking Hats" strategies and how it may help in risk decisions. It also includes:

(1) Key components of academic institutes risk management framework and summary risk register.

(2) Review examples of emerging risk from COVID-19 and propose a sequence for the discussion to reach decision on the control design and risk response.

(3) ABCD qualitative review of "Six Thinking Hats" methods as a tool for risk decisions.

\section{RESEARCH METHEDOLOGY :}

Secondary published data, including scholarly journals and website sources, are utilized to develop this case study. With the help of an example, this paper explores how "Six Thinking Hats" may serve as a decision aid and facilitate the risk decisions in an academic institution around risk appetite, risk identification, risk assessment, control design, and risk monitoring. Further, ABCD qualitative review of "Six Thinking Hats" strategies as a tool for risk decisions under four constructs, i.e., as proposed by the ABCD model, Advantages, Benefits, Constraints, and Disadvantages [12],[13].

\section{SIX THINKING HAT METHOD AND RISK DECISIONS :}

There are two main objectives of implementing the "Six Thinking Hats" process. First, it simplifies the thinking approach by encouraging participants to assess a situation with one style of thinking and hence brings clarity. Applying all styles of thinking or all colors of thinking to solve a problem is essential since one thinking style is not necessarily superior to another; it is just another way of looking at something; second, it requires the use of a variety of hats to include an order that promotes thinking without being offensive to any participant and therefore, encourages healthy decision-making and problem-solving culture. The "Six Thinking Hats" methods eliminate biases, opinions, and prejudices from the decision-making process by ensuring that all participants give answers and performances based on the hat's specific color, which in the absence of such approach may not be intuitive. The six thought hats reflect six distinct frames of mind defined in the form of a hat and each one has a different color. Table 2 below outlines six hats and examples of consideration in risk decisions

Table 2: "Six Thinking Hats" and examples of considerations for the risk decision

\begin{tabular}{|l|l|l|}
\hline $\begin{array}{c}\text { "Six Thinking } \\
\text { Hat" }\end{array}$ & \multicolumn{1}{|c|}{$\begin{array}{c}\text { "Six Thinking Hat" a Brief } \\
\text { Description }\end{array}$} & $\begin{array}{c}\text { Illustrative application of "Six Thinking } \\
\text { Hat" in risk management (examples) }\end{array}$ \\
\hline Red Hat & $\begin{array}{l}\text { Red is used to examine the } \\
\text { subjective viewpoint of risk decision }\end{array}$ & $\begin{array}{l}\text { a) What are potential failures first } \\
\text { impression (as may also be perceived }\end{array}$ \\
\hline
\end{tabular}




\begin{tabular}{|c|c|c|}
\hline & $\begin{array}{l}\text { making. Participants in these } \\
\text { situations will respond intuitively }\end{array}$ & $\begin{array}{l}\text { by stakeholders outside the meeting)? } \\
\text { Such a consideration can also provide } \\
\text { an excellent tool to know if deterrents } \\
\text { as risk mitigants have changed? } \\
\text { b) Initial emotional and gut feel about the } \\
\text { severity of the risk and likely } \\
\text { mitigants? }\end{array}$ \\
\hline Yellow Hat & $\begin{array}{l}\text { Yellow allows discussion to be from } \\
\text { a constructive viewpoint of decision } \\
\text { making to define the beneficial } \\
\text { aspects of the decision and provide } \\
\text { them with a logical justification and } \\
\text { promotes inclusion. }\end{array}$ & $\begin{array}{l}\text { a) What are the strengths/positive points } \\
\text { of exiting control designs to mitigate } \\
\text { new risk? } \\
\text { b) How useful does the university deploy } \\
\text { the current risk management } \\
\text { framework in a modified environment? } \\
\text { c) What are opportunities for leveraging } \\
\text { present artifacts, including risk register } \\
\text { and risk reporting tools to manage } \\
\text { enhanced risk, if any? }\end{array}$ \\
\hline Green Hat & $\begin{array}{l}\text { Green is used to discuss the creative } \\
\text { viewpoint on the risk decisions and } \\
\text { provides an opportunity to present } \\
\text { alternative ideas, possibilities and } \\
\text { enhance recommended ideas }\end{array}$ & $\begin{array}{l}\text { a) What are some ways to mitigate the } \\
\text { identified risk and keep the risk profile } \\
\text { within the institute's risk appetite? } \\
\text { b) What is another control design } \\
\text { available to achieve the same control } \\
\text { environment level and maintain risk } \\
\text { within the risk tolerance level? }\end{array}$ \\
\hline White Hat & $\begin{array}{l}\text { White focus on information } \\
\text { gathering, remain impartial in } \\
\text { explaining the truth and attempt to } \\
\text { evaluate the situation critically } \\
\text { without any preconceptions, } \\
\text { opinions, or feelings. }\end{array}$ & $\begin{array}{l}\text { a) What are the factual data i.e. is there a } \\
\text { gap in institutes risk register, do we } \\
\text { have instances or events where control } \\
\text { design is evidenced as ineffective, } \\
\text { what is the volume of new activity and } \\
\text { key risk indicators? } \\
\text { b) What is known e.g. external or internal } \\
\text { event of materialized risk } \\
\text { c) What is missing information to design } \\
\text { or enhance control and or evaluate the } \\
\text { risk decision? } \\
\text { d) How to obtain missing information or } \\
\text { is there a way to rely on proxy, control } \\
\text { data or metrics or how can team get } \\
\text { access to key missing information for } \\
\text { the risk decision?" }\end{array}$ \\
\hline Black Hat & $\begin{array}{l}\text { List the drawbacks, limitations and } \\
\text { residual risks }\end{array}$ & $\begin{array}{l}\text { a) Why will the proposed risk decision } \\
\text { and control design be ineffective in } \\
\text { mitigating the risk? } \\
\text { b) What is the deficiency of the treatment } \\
\text { plan or control design? } \\
\text { c) What is the limitation which will } \\
\text { restrict implementation of the } \\
\text { proposed risk decision and? } \\
\text { d) What are the challenges within which } \\
\text { institutes risk acceptance need to } \\
\text { operate, and how will that determine } \\
\text { the effectiveness of the proposed } \\
\text { control design? }\end{array}$ \\
\hline
\end{tabular}


Blue Hat
The blue hat is to control the process of thinking. It helps to coordinate other hats. a) In what order decision making should progress, e.g., risk identification may require Blue, White, Green, Blue or choosing between alternative control design may include Blue, White, Green, Yellow, Black, Red, Blue.

b) What risk decisions achieved and prioritization for next to target?

The technique may be implemented in a different sequence depending on which component of the risk framework is under review. Table 3 illustrates a recommended sequence to facilitate a control design decision where a new risk (e.g., information and cybersecurity) has just emerged and control design is proposed to be considered using "Six Thinking Hat" technique:

Table 3: Sample sequence of "Six Thinking Hats" to consider control design to mitigate enhanced information and cyber security risk (the sequence and description is illustrative)

\begin{tabular}{|c|c|}
\hline Sequence & $\begin{array}{l}\text { "Six Thinking Hats". A proposed sequence to discuss control design to } \\
\text { mitigate identified risk (Example) }\end{array}$ \\
\hline Step 1: Blue & $\begin{array}{l}\text { a) The chair begins the meeting by outlining the meeting's purpose and expected } \\
\text { outcome. Example, "The purpose of the discussion is to decide on the control } \\
\text { design for mitigating information and cybersecurity risk arising from the } \\
\text { adoption of novel technology tools that may not have undergone adequate } \\
\text { governance." } \\
\text { b) The chair may then provide sequence and time limits for each Hat. Example, } \\
\text { "Sequence for the meeting is Blue, White, Green, Red, Yellow, Black, Red, } \\
\text { and Blue. Blue may also interject at the appropriate time to bring the } \\
\text { discussion on track." }\end{array}$ \\
\hline Step 2: White & $\begin{array}{l}\text { The chair may then provide sequence and time limits for each Hat. Example, } \\
\text { "Sequence for the meeting is Blue, White, Green, Red, Yellow, Black, Red, and } \\
\text { Blue. Blue may also interject at the appropriate time to bring the discussion on } \\
\text { track." }\end{array}$ \\
\hline Step 3: Green & $\begin{array}{l}\text { This time of the meeting is to generate ideas to provide alternatives for mitigating } \\
\text { risk. Example, "Based on the factual information, the option may include } \\
\text { outsourcing risk by having a cyber or performing a thorough cybersecurity risk } \\
\text { assessment for the technology adopted by staff and student or restricting the use } \\
\text { of particular technology as same is outside the risk appetite of the university." }\end{array}$ \\
\hline Step 4: Red & $\begin{array}{l}\text { Fist of five voting or similar mechanism to capture instinctive reaction on the } \\
\text { proposed alternatives Example, "Chair invites participants to use fist of five to } \\
\text { vote the most effective alternative, i.e., insurance policy, risk assessment of each } \\
\text { technology or restrict technology or supplement it with additional third-party } \\
\text { technology to bring the risk profile within the acceptable risk tolerance." }\end{array}$ \\
\hline Step 5: Yellow & $\begin{array}{l}\text { List the benefits of the preferred risk mitigant. Example, "list benefits, e.g., } \\
\text { performing a thorough risk assessment of technology will enable future } \\
\text { collaboration opportunities. This mitigant will create in-house cyber risk } \\
\text { capabilities to take on future cyber challenges. It will also allow the university to } \\
\text { embark on a new revenue stream by partnering with EduTech to offer new } \\
\text { programs across the country and globe on a digital model." }\end{array}$ \\
\hline Step 6: Black & $\begin{array}{l}\text { List the challenges and limitations of the preferred risk mitigant. Example, "this } \\
\text { will mean risk remediation will take time and institute may need to operate outside } \\
\text { the acceptable tolerance level for a few months. This mitigant will require } \\
\text { additional investment." }\end{array}$ \\
\hline
\end{tabular}




\begin{tabular}{|l|l|}
\hline Step 7: Red & $\begin{array}{l}\text { Fist of five voting or similar mechanism to capture decision on the proposed } \\
\text { mitigant, i.e., accept or reject based on gut feeling }\end{array}$ \\
\hline Step 8: Green & $\begin{array}{l}\text { Discuss means to overcome the limitations and challenges of the selected option. } \\
\text { Example, "develop a tactical plan in the interim to improve risk profile." }\end{array}$ \\
\hline Step 9: Blue & $\begin{array}{l}\text { The chair may finally end the meeting by summarizing the outcome and action } \\
\text { plans, both strategic and tactical, and close the meeting }\end{array}$ \\
\hline
\end{tabular}

\section{ACADEMIC ISTITUTIONS RISK MANGEMENT COMPONENTS:}

Enterprise Risk Management framework at the academic institution provides strategies, standards, tools, and procedures to mitigate uncertainties to accomplish their mission and goals. This framework usually includes identifying risk inherent in the institution's design and consists of both threats and opportunities, identifying risk mitigants for such identified risk, and tracking processes to ensure they operate within the institution's risk appetite[1]-[3], [16]-[20]. Therefore, the framework requires that academic institutions, from time to time, need to take risk decisions, e.g., avoid risk, accept the risk, reduce risk, or transfer risk. The "Six Thinking Hats" method provides key risk decision-makers with an opportunity to consider the full discussion, produces alternative solutions, and allows for the optimum risk-balanced decision to mitigate the potential failures. Table 4 below illustrates sequence of "Six Thinking Hat" which may be adopted for each component or stage of the enterprise risk management framework by academic institutions.

Table 4: "Six Thinking Hat" and components of the risk management framework

\begin{tabular}{|c|c|c|}
\hline S. No. & Key Risk Management Components & $\begin{array}{c}\text { Illustrative sequence of "Six Thinking Hat" } \\
\text { - Risk component }\end{array}$ \\
\hline 1 & $\begin{array}{l}\text { Risk appetite and tolerance - The degree } \\
\text { and nature of risk an academic institution } \\
\text { and its faculties or divisions is willing to } \\
\text { pursue and accept to achieve its mission. }\end{array}$ & $\begin{array}{l}\text { This is a strategic decision and have long term } \\
\text { implication on the performance and reputation } \\
\text { of the institution. Sample sequence - Blue, } \\
\text { Yellow, Black, White, Blue, Green, Blue }\end{array}$ \\
\hline 2 & $\begin{array}{l}\text { Risk, causes, impact identification - } \\
\text { This includes identifying what could } \\
\text { happen, how and why it could happen, } \\
\text { and its potential impact. }\end{array}$ & $\begin{array}{l}\text { This is an iterative process and sample } \\
\text { sequence } \\
\text { a) Create initial risk profile - a recommended } \\
\text { sequence, Blue, White, Green, Blue } \\
\text { b) Assess the risk profile for completeness } \\
\text { against risk appetite for the top risks, a } \\
\text { recommended sequence, Blue, Yellow, } \\
\text { Black, White, Blue, Green, Blue } \\
\text { c) Finally get quick feedback (outside the } \\
\text { group discussion risk profile), a } \\
\text { recommended sequence, - Blue, Black, } \\
\text { Green, Blue }\end{array}$ \\
\hline 3 & $\begin{array}{l}\text { Control design assessment - This } \\
\text { includes identifying and mitigating risk } \\
\text { arising from each of the causes to ensure } \\
\text { all the key risks within the acceptable risk } \\
\text { tolerance of academic institution or } \\
\text { faculty or division }\end{array}$ & $\begin{array}{l}\text { This is a strategic and have long term impact } \\
\text { on maintaining a risk profile. Sample sequence } \\
\text { Identifying control designs -Blue, White, } \\
\text { Black, Green, Blue } \\
\text { a) Choosing most efficient and effective } \\
\text { control design -Blue, White, Green, Red, } \\
\text { Yellow, Black, Red, Green, Blue } \\
\text { b) Control design improvement based on } \\
\text { feedback from control monitors - Blue, } \\
\text { White, White, Yellow, Black, Green, Red, } \\
\text { Blue }\end{array}$ \\
\hline
\end{tabular}


\begin{tabular}{|l|l}
\hline 4 & Risk monitoring and treatment - This
\end{tabular} includes deciding on adequate risk monitors to track the control design and execution effectiveness, assessing it against the tolerance and proposing additional remediation plans where controls are not designed or operating effectively
This is a strategic to monitor control design effectiveness

a) Identifying control monitors to assess effectiveness of control design and execution -Blue, White, Black, Green, Blue

b) Assess monitor results against the risk tolerance - Blue, Red, White, Yellow, Black, Green Red, Blue

\section{ABCD QUALITATIVE ANALYSIS OF SIX HAT THINKING AS TOOL FOR RISK DECISIONS:}

$\mathrm{ABCD}$ analysis tool provides an opportunity to evaluate the benefits, advantages, constraints, and disadvantages of any proposed solution, concept, or method, etc [7], [10], [12], [13], [21]-[23].

\subsection{Advantages:}

(1) Improves interdisciplinary collaboration and promotes the participation of all the group members.

(2) It eliminates exertion of ego in discussion and forces positive and systematic thinking.

(3) Promotes understanding of the various viewpoints as risk may have an impact across multiple aspects of the university on the topic and thereby provides an opportunity to take a more informed decision.

(4) Promotes lateral thinking one thinking mode at a time.

(5) Flexible to rearrange sequence depending on the nature of risk decision.

\subsection{Benefits:}

(1) The technique may be used in conjunction with other management decision and problem-solving models' example, SWOT, SWOC, McKinsey 7S, PEST, ICDT, or Portor's five force model.

(2) Support different risk management framework components and could be adopted as a useful tool for identifying, developing, and validating risk decisions.

(3) It provides a structured approach, removes bias, and demonstrates strong governance in decisionmaking.

(4) Improves team bonding and improves team dynamic as each style of thinking is valued and considered as part of decision making.

(5) It allows proportionality of different factors in decision making.

\subsection{Constraints:}

(1) The process is time-intensive and requires considerable planning as participants may be inexperienced with the activity and may need significant guidance throughout the process.

(2) The chair or moderator needs to monitor the time spent on each style.

(3) Any or some of the "Six Hat Thinking" mode may not be a usual way of thinking and may make participants feel anxious during the process.

(4) Risk decisions at many times require immediate action and arriving at consensus may be timeconsuming and hence unsuitable in those scenarios.

\subsection{Disadvantages:}

(1) Conflicts can occur due to different viewpoints, which can complicate the procedure.

(2) Where participants are unfamiliar with the technique, the result could be substandard.

(3) The process may require increased meeting administrative efforts.

(4) A bias in the process incur due to increasing frequency and time spent on a thinking style.

(5) There may be a possibility of blame game and unwarranted conflict if where the outcome is not favorable.

\section{CONCLUSIONS :}

Academic institutions continually recognize that implementing a robust risk framework and exercising 
appropriate risk decisions are the core components of strategic planning and achieving mission. COVID-19 has provided enough evidence that organizations of all sorts face daunting environmental, political, socio-economic, and cultural forces that make their operational environments unpredictable and reinforces the importance of risk management practice in an academic institution. The current COVID-19 environment is further posing new risks to the educational institutions, e.g., enhanced information and cybersecurity risk, deterioration in the effectiveness of traditional fraud risk mitigants, and increased risk of financial viability. These emerging risks can alter academic institutions' risk profile and hence require careful risk assessment and risk decisions, not merely but one mode of thinking. "Six Thinking Hat" techniques may provide a helpful framework and decision aid for making risk decisions. The article does not take a rigorous test of "Six Thinking Hat" types in risk decisionmaking areas; however, it explores application through examples. Researchers and future work may find this to be a useful line of inquiry in the future.

\section{REFERENCES:}

[1] Huber, M. (2011). The Risk University Risk identification at higher education institutions in England. Centre for Analysis of Risk and Regulation at the London School of Economics and Political Science, 1(1), 1-21.

[2] Cameron, C. \& Klopper, C. (2015). University lawyers a study of legal risk, risk management and role in work integrated learning programmes. Journal of Higher Education Policy and Management, 37(3), 1-17.

[3] Malki, S. \& Aldwais, N. K. (2019). Enterprise Risk Management at the State University of New York: A Benchmark for Saudi Universities. Journal of Applied Business and Economics, 21(9), 54-74.

[4] Singh, U. K. \& Joshi, C. (2017). Information security risk management framework for University computing environment. International Journal of Network Security, 19(5), 742-751.

[5] Edward de Bono (1999) Six Thinking Hats. Back Bay Books, New York.

[6] Aithal, P. S. \& Suresh Kumar, P. M. (2016). Using Six Thinking Hats as a Tool for Lateral Thinking in Organizational Problem Solving. International Journal of Current Research and Modern Education (IJCRME), 1(2),169-185.

[7] Aithal, P. S., Shailashree V. T. \& Suresh Kumar P. M. (2016). Analysis of ABC Model of Annual Research Productivity using ABCD Framework. International Journal of Current Research and Modern Education (IJCRME), 1(1), 846-858.

[8] Aithal, P. S. \& Suresh Kumar, P. M. (2017). Integrating Theory A and Six Thinking Hats Technique for Improved Organizational Performance. International Journal of Applied Engineering and Management Letters (IJAEML), 1(2), 66-77.

[9] Aithal, P. S. \& Suresh Kumar, P. M. (2017). Ideal Analysis for Decision Making in Critical Situations through Six Thinking Hats Method. International Journal of Applied Engineering and Management Letters (IJAEML), 1(2), 1-9.

[10] Aithal, P. S. \& Suresh Kumar, P. M. (2017). Managerial Decision Making Through Six Thinking Hats Technique. International Journal of Scientific Research and Modern Education (IJSRME), 2(1), 53-58.

[11] Aithal, P. S. \& Suresh Kumar, P. M. ( 2017) How Six Thinking Hats Method can be used as Ideal Analysis Technique for Situations. International Journal of Scientific Research and Modern Education (IJSRME), 1(2), 225-234.

[12] Aithal, P. S. (2015). Study on ABCD Analysis Technique for Business Models, business strategies, Operating Concepts \& Business Systems. International Journal in Management and Social Science, 4(1), 98-115.

[13] Aithal, P. S., Shailashree V. T. \& Suresh Kumar P. M. (2015). A New ABCD Technique to Analyse Business Models \& Concepts. Int. J. Manag. IT Eng, 5(4), 409 - 423.

[14] Brewer, A. \& Walker, I. (2011). Risk management in a university environment. Journal of Business Continuity \& Emergency Planning, 5(2), 19 - 27. 
International Journal of Case Studies in Business, IT, and Education (IJCSBE), ISSN: 2581-6942, Vol. 4, No. 2, December 2020

[15] Sum, R. M, \& Saad, Z. M. (2017). Risk Management in Universities. 3rd International Conference on Qalb Guided Leadership in Higher Education. iQ(2017), 128 - 142.

[16] Wyma, K. M. (2019). Enterprise Risk Management Strategies for Organizational Walden University. Walden Dissertations and Doctoral Studies, 81(6A), 1 - 193.

[17] Ruzic-Dimitrijevic, L. \& Dakic, J. (2014). The risk management in higher education institutions. Online Journal of Applied Knowledge Management, 2(1), 137-152.

[18] Ndudzo, P. D. (2017). Enterprise Risk Management in ODL: The Imperatives and Lessons from the Zimbabwe Open University. IOSR Journal of Business and Management, 19(01), 24 - 28

[19] Bruhn, A., Whiting, B., Browne, B., Higgins, T. \& Tan, C. I. (2017). Introducing Enterprise Risk Management Into the University Classroom: A Case Study. Risk Management and Insurance Review, 20(1), 99 - 131.

[20] Verbrugge, J. (2020). Enterprise-Wide Risk Management. Journal of Applied Corporate Finance, $32(1), 14-35$.

[21] Aithal, P. S. (2017). Industry Analysis - The First Step in Business Management Scholarly Research. International Journal of Case Studies in Business, IT and Education (IJCSBE), 2(1), 113.

[22] Aithal, P. S. (2017). Company Analysis - The Beginning Step for Scholarly Research. International Journal of Case Studies in Business, IT and Education (IJCSBE), 1(1), 1-18.

[23] Aithal, P. S. (2017). An Effective Method of Developing Business Case Studies Based on Company analysis. International Journal of Engineering Research and Modern Education (IJERME), 2(1), 16-27.

$* * * * * * * * * * *$ 